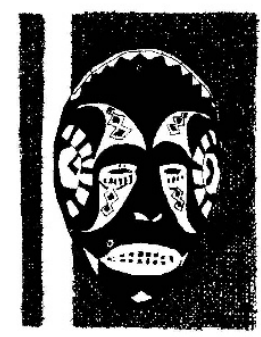

\title{
Black Woman Talk Black Woman Talk Collective
}

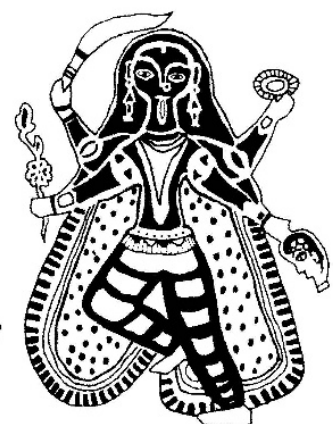

Black Woman Talk is a collective of women of Asian and African descent living in Britain. As Black women we feel that the publishing industry has ignored and silenced the views and ideas of Black women living in Britain. It is important for us therefore to restore the lines of communication which have been historically destroyed and to reestablish the links between our scattered and isolated communities.

As Black women we experience oppression due to our sex, race, class and sexual orientation. This is reflected in every area of our lives and the publishing industry is no exception. It is a very powerful medium for communication and it reflects the racism and sexism of this society. The amount of work published for, by and about Black women is totally negligible and Black women's voices have gone unheard. Instead racist and sexist stereotypes have been perpetuated and until now been unchallenged.

More recently, it appears that there is a growing awareness amongst some of the established mainstream and feminist publishers of the need to make Black voices heard. Unfortunately, their enthusiasm to publish works by Black women, particularly from America, seems to stem from their recognition that such books have a lucrative market, rather than any genuine commitment to making publishing accessible to Black women writers in Britain. Afro-American women seem to be the vogue for feminist publishers such as the Women's Press. Such publishers are not only reluctant to hear the voices of Black women in Britain but there is little concern about including Black women in the publishing industry in a way which gives them any decision-making powers at all levels.

Black Woman Talk began as a small group of unemployed women who came together to form a workers' publishing co-operative. We feel there is an urgent need to see more publications available by Black women living in Britain to express our experiences and history. Our own varied experiences in working in Black organizations as well as our varied involvement in creative work such as writing, visual arts, theatre and music places us in contact with Black women who are writing and/or doing visual work. We are all writers and artists who want to see more Black women get access to publishing and the various skills involved in this field.

Black Woman Talk aims to provide a means by which women of Asian and African descent can publish their work, and through the publication of short stories, poetry, political writings, photo-essays, calendars reflect the wide variety of written and visual works produced by us. We would like to encourage more Black women to write and record their life experiences and to provide a greater knowledge and understanding of the lives and history of Black women in the wider community. We would also like to make alternative materials available for use in schools, libraries and other public information centres.

We will shortly be asking for manuscripts by Black women and as we grow we shall provide employment in a co-operative situation where Black women work with and for other Black women, thus sharing the skills and knowledge we gain, and providing encouragement and advice to other Black women. We would like to extend to cover typesetting and printing in the long term, which would give us greater selfdetermination and more skills to share.

The existence of Black Woman Talk is testimony to the strength of Black Women organizing to create our own means of communication. The international movement of Black women organizing in this way is illustrated by the existence of our sister press in America, Kitchen Table; Women of Color Press, and Kali Press; Third World Women Press in Delhi. 